\title{
Propelling Healthcare with Advanced Therapy Medicinal Products: A Policy Discussion
}

\author{
Denis Horgan $^{a} \quad$ Andres Metspalu $^{b}$ Marie-Christine Ouillade ${ }^{c}$ \\ Dimitrios Athanasiou $^{d}$ John Pasi ${ }^{\text {e }}$ Oumeya Adjali ${ }^{f}$ Patrick Harrison ${ }^{9}$ \\ Cedric Hermans $^{h} \quad$ Giovanni Codacci-Pisanelli ${ }^{i}$ Jasmina Koeva ${ }^{j}$ \\ Thomas Szucs $^{k}$ Viorica Cursarul Ivica Belinam Chiara Berninia \\ Suijie Zhuang $^{\mathrm{n}}$ Stephen McMahon $^{\circ}$ Draga Toncheva $^{\mathrm{p}} \quad$ Thomas Thum $^{q}$ \\ aEuropean Alliance for Personalised Medicine, Brussels, Belgium; ${ }^{b}$ Estonian Genome Center \\ of the University of Tartu, Tartu, Estonia; 'French Muscular Dystrophy Association (AFM), \\ Evry, France; ${ }^{d}$ World Duchenne Organization, Veenendaal, The Netherlands; ${ }^{\text {B Barts and the }}$ \\ London School of Medicine and Dentistry, Queen Mary University of London, London, UK; \\ fUniversite de Nantes, Nantes, France; gUniversity College Cork, Cork, Ireland; hUniversité \\ Catholique de Louvain, Louvain, Belgium; 'Università La Sapienza, Rome, Italy; ${ }^{j}$ Bulgarian \\ Alliance for Personalised and Precision Medicine, Sofia, Bulgaria; ${ }^{k}$ University of Basel, \\ Basel, Switzerland; 'Myeloma Euronet Romania, Bucharest, Romania; ${ }^{\mathrm{m} K U Z}$ - Coalition of \\ Association in Healthcare, Zagreb, Croatia; ' F.Hoffmann - La Roche AG, Basel, Switzerland;

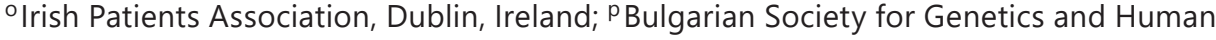 \\ Genomics, Sofia, Bulgaria; ${ }^{9}$ Institute of Molecular and Translational Therapeutic Strategies \\ (IMTTS), Hannover Medical School, Hannover, Germany
}

\section{What Is It about?}

Advanced therapy medicinal products (ATMPs) are improving the prospects for tackling severe disease - in many cases diseases that at present have no treatment - and the science and technology involved is intimately linked to Europe's broader development of new approaches to healthcare, dependent on early diagnosis and more personalised healthcare. There are some outstanding challenges across regulatory, scientific, manufacturing, and market access fields. This paper makes specific recommendations for all stakeholders, ranging from early dialogue on potential products, linking of clinical data, and patient registries or standardisation of control frameworks, to a comprehensive approach to evidence generation, assessment, pricing, and payment for ATMPs.

\section{Keywords}

European Union - Gene therapy · Gene transfer - Personalised healthcare · Personalised medicine $\cdot$ Policy $\cdot$ Quality of life $\cdot$ Tissue engineering $\cdot$ Vector design · Virus 
Horgan et al.: Propelling Healthcare with ATMPs

\begin{abstract}
Recent advances in biomedicine are opening the door to new approaches, and treatment and prevention are being transformed by novel medicines based on genetic engineering, innovative cell-based therapies and tissue-engineered products, and combinations of a medical device with embedded cell or tissue components. These advanced therapy medicinal products (ATMPs) hold one of the keys to making a reality of genuinely personalised medicine. There are an estimated 450 companies across the globe working on the development of gene therapies and more than 1,000 clinical trials underway worldwide, and some 20-30 new ATMPs filings are expected in Europe annually over the next 5 years. But challenges confront the sector, complicating the translation from research into patient access. Scientific, clinical development and regulatory issues are compounded by limited experience with clinical and commercial use, limited manufacturing know-how, high costs, and difficulties in accessing development funding and investment. Pricing and reimbursement and market access issues are an additional challenge, particularly in Europe, where unfamiliarity with the technology and uncertainty over the use of real-world evidence induce caution among clinicians, health technology assessment bodies and payers. There is a need for a review of the suitability of the regulatory and market access framework for these products, focused development of data, public/ private partnerships, and fuller collaboration governments, doctors, insurers, patients, and pharmaceutical companies. This paper makes specific recommendations for all stakeholders, ranging from early dialogue on potential products, linking of clinical data and patient registries or standardisation of control frameworks, to a comprehensive approach to evidence generation, assessment, pricing, and payment for ATMPs.

(c) 2020 The Author(s)

Published by S. Karger AG, Basel
\end{abstract}

\title{
Introduction: The Potential
}

Recent advances in biomedicine are opening the door to new approaches - particularly for diseases such as cancer and rare diseases, where limited or no alternative treatment options exist and unmet need remains high. Treatment and prevention is being transformed by novel and complex medicines based on genetic engineering, innovative cell-based therapies and tissue-engineered products, and combinations of a medical device with embedded cell- or tissue components.

These products - which are known in the EU as advanced therapy medicinal products (ATMPs) - have the potential to provide life-changing benefits to patients and their families, and potentially curative options to patients with unmet medical need. After a slow start, the field is at last advancing fast, as demonstrated by the number and variety of clinical trials and the new products now becoming available. ATMPs have already demonstrated outstanding results in treatment in patients with B-cell acute lymphoblastic leukaemia, melanoma, lymphoma, and rare inherited disorders such as treatment of children with spinal muscular atrophy (SMA) or vision loss due to retinal dystrophy. They hold one of the keys to making a reality of genuinely personalised medicine [1].

European Medicines Agency's (EMA's) own regulatory strategy for 2025 placed cellbased therapies at the top of the list of the "transformational research that is having a significant impact on the regulatory science agenda." ATMPs "have great potential to address unmet medical need," it goes on. Gene therapy medicinal products may provide cures for several monogenetic diseases, as genome editing includes correction or inactivation of deleterious mutations, introduction of protective mutations, and addition of therapeutic transgenes and disruption of viral DNA [2]. Gene therapy has also been described as an experimental technique that uses genes to treat, cure, or prevent disease, with the goal to achieve 
durable expression of the therapeutic gene or "transgene" at a level sufficient to ameliorate or cure disease symptoms with minimal adverse events. Gene therapy is defined by the American Medical Association as "a novel approach to treat, cure, or ultimately prevent disease by changing the expression of a person's genes," and it functions via repair, deactivation, or replacement of dysfunctional genes that cause disease, with the aim of (re)establishing normal function. DG RTD says that after 20 years of EU research programmes supporting the entire innovation chain for gene transfer and gene therapy, the fruits of this investment are now ripening [3].

But despite the unique possibilities of these technologies, there are some outstanding challenges across regulatory, scientific, manufacturing, and market access fields that still hamper the ability to deliver the potential. Gene therapies display a number of specific characteristics challenging the current healthcare systems' paradigm. They have, at present, uncertain outcomes. They are "one-off and once-only treatments," as single treatments for chronic disease, for - at present - limited populations only, and possibly offering life-changing improvements. But their use is limited to centres of excellence with the necessary specialised facilities and personnel, and subject to special requirements on adverse effects management, long-term follow-up and logistics.

This publication sets out the achievements to date with this new group of products, the principal challenges to their development, some possible immediate ways ahead, and the longer-term options for integrating ATMPs into more impactful healthcare systems that capitalise on the opportunities of personalised medicine.

\section{The Achievements to Date}

Since 2000, when the optimism of the gene therapy research community was bolstered by the first report of successful treatment of a genetic disease by gene therapy, there has been a trickle of innovations [4]. The beauty of that early breakthrough - GlaxoSmithKline's Strimvelis in X-linked severe combined immunodeficiency due to adenosine deaminase deficiency, a rare metabolic disorder most commonly diagnosed in early infancy (and often known as "bubble baby syndrome") - was its purity [5]. ADA-SCID is caused by mutations in the enzyme ADA, leading to the aberrant development of $\mathrm{T}$ and $\mathrm{B}$ cells, immunodeficiency, and the risk of opportunistic infections. Some patients can be treated with bone marrow transplants from healthy donors, but immune matching from donors is never perfect and immune incompatibility can lead to rejection. With Strimvelis, the patient's own bone marrow is removed, and the cells are treated with a viral vector that inserts the ADA gene into cellular DNA. Gene-corrected cells are then re-introduced into the patient, obviating the risk of rejection [6].

But it took time to move from concept to patient administration. Strimvelis was not authorised until 2016. And it was only the second gene therapy to be approved in Europe. It followed UniQure's Glybera (alipogene tiparvovec), approved in 2012 for the treatment of lipoprotein lipase deficiency, which was marketed briefly in Germany and Italy, but only ever treated one patient. Glybera's authorisation was allowed to lapse in 2017, since it was commercially non-viable. Strimvelis too - now marketed by Orchard Therapeutics - has struggled for commercial viability. It has treated 160 patients but is still described by Orchard as "a problem child" [7, 8].

These early examples are not atypical of the challenges inherent in developing and providing access to ATMPs. The path to exploiting the technology has been difficult despite years of extensive and intensive activity among drug developers and regulators. Between 2009 and 2017, 500 clinical trials are recorded with ATMPs, but they resulted in only 19 market authorisation applications to the European Medicines Agency, and only ten ATMPs received a marketing authorisation. Of these, three were later withdrawn by their companies,

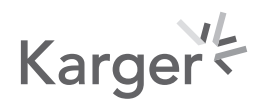




\begin{tabular}{|c|c|c|c|c|c|}
\hline \multicolumn{3}{|r|}{ In vivo } & \multicolumn{3}{|r|}{ Ex vivo } \\
\hline $\begin{array}{l}\text { Name } \\
\text { (Company) }\end{array}$ & $\begin{array}{l}\text { Date } \\
\text { approved }\end{array}$ & Description & $\begin{array}{l}\text { Name } \\
\text { (Company) }\end{array}$ & $\begin{array}{l}\text { Date } \\
\text { approved }\end{array}$ & Description \\
\hline $\begin{array}{l}\text { Gendicine } \\
\text { (Benda Pharma) }\end{array}$ & Oct 2003* & $\begin{array}{l}\text { Adenovirus with the p53 tumor-suppressor gene for } \\
\text { head \& neck cancer }\end{array}$ & \multirow[t]{2}{*}{$\begin{array}{l}\text { Provenge } \\
\text { (Dendreon) }\end{array}$} & \multirow[t]{2}{*}{ Apr $2010 * * *$} & \multirow{2}{*}{$\begin{array}{l}\text { Dendritic cells extracted and viral transfection with a } \\
\text { recombinant fusion protein and then reinfused to treat } \\
\text { metastatic prostate cancer }\end{array}$} \\
\hline \multirow{2}{*}{$\begin{array}{l}\text { Oncorine } \\
\text { (Shanghai Sunway } \\
\text { Biotech) }\end{array}$} & \multirow[t]{2}{*}{ Nov 2005* } & \multirow[t]{2}{*}{$\begin{array}{l}\text { Oncolytic recombinant adenovirus for nasopharyngeal } \\
\text { cancer with chemotherapy }\end{array}$} & & & \\
\hline & & & \multirow{2}{*}{$\begin{array}{l}\text { Strimvelis } \\
\text { (GSK/Orchard) }\end{array}$} & \multirow[t]{2}{*}{ May $2016 * *$} & \multirow{2}{*}{$\begin{array}{l}\text { Bone marrow cells are extracted and transfected with a } \\
\text { gamma retrovirus to treat adenosise deaminase severe } \\
\text { combined immunodeficiency deficiency (ADA-SCID) }\end{array}$} \\
\hline Glybera (uniQure) & Nov 2012** & AAV1 treatment for lipoprotein lipase deficiency & & & \\
\hline \multirow{2}{*}{$\begin{array}{l}\text { Kynamro } \\
\text { (Kastle) }\end{array}$} & \multirow{2}{*}{$\operatorname{Jan} 2013^{* * *}$} & \multirow{2}{*}{$\begin{array}{l}\text { Antisense oligomer which treats homozygous familial } \\
\text { hypercholesterolemia }\end{array}$} & \multirow{3}{*}{$\begin{array}{l}\text { Zalmoxis } \\
\text { (MolMed) }\end{array}$} & \multirow{3}{*}{ Aug $2016^{* *}$} & \multirow{3}{*}{$\begin{array}{l}\text { Adjunct treatment for graft vs. host disease (GvHD) in } \\
\text { bone marrow transplants with "suicide switch." retrovirus } \\
\text { gene insertion into donor T-cells infused to patient }\end{array}$} \\
\hline & & & & & \\
\hline Imlygic (Amgen) & Nov 2015 & HSV -1 Virus to treat melanoma lesions & & & \\
\hline $\begin{array}{l}\text { Exondys51 } \\
\text { (Sarepta) }\end{array}$ & Sep 2016*** & $\begin{array}{l}\text { Anti-sense oligomer for exon skipping to treat Duchenne } \\
\text { muscular dystrophy (DMD) }\end{array}$ & \multirow[t]{2}{*}{$\begin{array}{l}\text { Kymriah } \\
\text { (Novartis) }\end{array}$} & \multirow[t]{2}{*}{ Aug 2017} & \multirow{2}{*}{$\begin{array}{l}\text { Patient's T-cells are extracted and CAR targeting CD19 } \\
\text { inserted using lentivirus for reinfusion for pALL \& } \\
\text { DLBCL }\end{array}$} \\
\hline $\begin{array}{l}\text { Spinraza } \\
\text { (Biogen/lonis) }\end{array}$ & Dec 2016 & $\begin{array}{l}\text { Anti-sense oligomer for alternate gene splicing for } \\
\text { spinal muscular atrophy (SMA) }\end{array}$ & & & \\
\hline $\begin{array}{l}\text { Luxturna } \\
\text { (Spark) }\end{array}$ & Mar 2018 & AAV2 treatment for RP caused by RP165 gene & \multirow[t]{2}{*}{$\begin{array}{l}\text { Yescarta } \\
\text { (Kite/Gilead) }\end{array}$} & \multirow[t]{2}{*}{ Oct 2017} & \multirow[t]{2}{*}{$\begin{array}{l}\text { Patient's T-cells are extracted and CAR targeting CD19 } \\
\text { inserted using retrovirus for reinfusion for DLBCL }\end{array}$} \\
\hline \multirow[t]{4}{*}{$\begin{array}{l}\text { Onpattro } \\
\text { (Alnylam) }\end{array}$} & Aug 2018 & $\begin{array}{l}\text { RNAi drug to treat adult hereditary transthyretin } \\
\text { amyloidosis }\end{array}$ & & & \\
\hline & & & & & *Only approved in China \\
\hline & & & & & $* *$ Only approved in the EU \\
\hline & & & & & $* * *$ Only approved in the USA \\
\hline
\end{tabular}

Fig. 1. Approved and marketed gene therapies.

and one discontinued marketing - all of them citing commercial reasons, according to the most recent published survey conducted among companies [9].

Since the European Medicines Agency's first recommendation for approval of an ATMP containing stem cells, there was one more in 2015, two in 2016, two in 2017, three in 2018, and only one in 2019. Research into ATMPs is growing, as demonstrated by the 511 clinical trials conducted from 2011 to 2014 for 303 different ATMPs, and the trickle is beginning to show signs of turning into a steady stream. In 2020, the arsenal of approved and marketed ATMPs has widened, and they are now demonstrating their effectiveness in a range of health conditions [10] (Fig. 1).

In the field of cancer, CAR-T cell therapies (chimeric antigen receptor T-cell therapy) are providing new hope for patients. These are complex medicinal products, with therapy tailormade for every patient: specific immune cells are isolated from the patient's blood and processed to recognise and attack the cancer cells after being returned to the patient. The first two of these highly anticipated advanced therapies - Novartis's Kymriah (tisagenlecleucel) and Gilead's Yescarta (axicabtagen ciloleucel), both approved in large B-cell lymphomas in 2018 - have had some demonstrated success, and are good example of the new possibilities that personalised medication can bring, especially for vulnerable patients who often have no time to lose [11].

Innovations have become available in other conditions. A novel gene therapy for a rare form of vision loss through inherited retinal dystrophy won approval in 2018 - Luxturna (voretigene neparvovec), marketed by Novartis/Spark Therapeutics at GBP 613,410 [12].

A treatment for a rare inherited blood disorder, transfusion-dependent $\beta$-thalassaemia, was conditionally approved in the EU in June 2019. Zynteglo (betibeglogene autotemce) (lentiglobin), from bluebird bio, was launched in Germany in January at a hospital price of EUR 1.575 million [13]. 


\begin{tabular}{|c|c|c|c|c|c|}
\hline & Novartis & Bluebird Bio & Novartis & Novartis & Gilead \\
\hline & Luxturna ${ }^{\circledR}$ & Zynteglo ${ }^{\circledR}$ & Zolgensmar ${ }^{\circledR}$ & Kymriah ${ }^{\circledR}$ & Yescarta ${ }^{\circledR}$ \\
\hline & AAV2 vector & Lentiviral vector & AAV9 vector & CAR-T & CAR-T \\
\hline One-off-treatment & $\begin{array}{l}\text { In vivo, single subretinal } \\
\text { injection }\end{array}$ & Ex vivo, single IV infusion & $\begin{array}{l}\text { In vivo, single IV infusion } \\
\text { in peripheral vein }\end{array}$ & Ex vivo, single IV infusion & Ex vivo, single IV infusion \\
\hline $\begin{array}{l}\text { Limited } \\
\text { population }\end{array}$ & $\begin{array}{l}\text { US: } 1,000-2,500 \\
\text { EU28: } 1,500-4,000\end{array}$ & $\begin{array}{l}\text { US: } 1,000+ \\
\text { EU28: } 2,500-3,500\end{array}$ & EU28: $550-600$ infants & $\begin{array}{c}\text { ALL \& DLBCL in EU28: } \\
3,000-6,000\end{array}$ & DLBCL: $2,000-5,000$ \\
\hline $\begin{array}{l}\text { Potentially } \\
\text { curative }\end{array}$ & $\begin{array}{l}\text { Curative promise: } \\
\text { blindness reversion } \\
\text { in inherited retinal disease }\end{array}$ & $\begin{array}{l}\text { Curative promise: } \\
\text { transfusion independence } \\
\text { in beta-thalassemia }\end{array}$ & $\begin{array}{l}\text { Curative and life-saving promise: } \\
\text { SMA I }\end{array}$ & $\begin{array}{l}\text { Life-prolonging } \\
\text { in DLBCL and ALL, re-dosed in } \\
\text { few patients }\end{array}$ & $\begin{array}{l}\text { Life-prolonging } \\
\text { in DLBCL and primary } \\
\text { metastatic B-cell lymphoma, re- } \\
\text { dosed in few patients }\end{array}$ \\
\hline Ground-breaking & $\begin{array}{l}\text { Significant improvement in } \\
\text { VA in } 11 / 20(55 \%) \text { of } \\
\text { the } 1 \text { st eye, } 4 / 20(20 \%) \text { of } \\
\text { the second-treated eyes }\end{array}$ & $\begin{array}{c}15 / 19(79 \%) \text { achieved } \\
\text { transfusion-independence } \\
\text { at } 2 \text { years }\end{array}$ & $\begin{array}{c}\text { Survival at } 24 \mathrm{~m} 12 / 12(100 \%) \\
\text { in phase I, } 1 \text { patient died } \\
\text { due to disease progression } \\
\text { in phase III }\end{array}$ & $\begin{array}{l}\text { ALL } 12 \text { m: ORR } 61 / 75(81 \%), \\
\text { OS } 49 \% \\
\text { DLBCL } 12 \text { m: ORR } 48 / 93(52 \%), \\
\text { OS } 77 \%\end{array}$ & $\begin{array}{l}12 \mathrm{M} \text { ORR } 74 \%(75 / 101) \\
12 \mathrm{M} \text { OS } 60 \%(60 / 101) \\
24 \mathrm{M} \text { OS } 51 \%(51 / 101)\end{array}$ \\
\hline $\begin{array}{l}\text { Uncertainty of } \\
\text { outcomes }\end{array}$ & $\begin{array}{l}\text { Total studied in } 41 \text { subjects } \\
\text { (21 Luxturna pts in phase III), } \\
1 \text { year primary endpoint }\end{array}$ & $\begin{array}{l}\text { Studied in } 32 \text { subjects } \\
2 \text { year primary endpoint, } \\
\text { up to } 48 \mathrm{~m} \text { of follow up }\end{array}$ & $\begin{array}{l}\text { Studied in } 36 \text { subjects } \\
\text { 14-18 } \mathrm{m} \text { primary endpoints, } \\
\text { upto } 24 \mathrm{~m} \text { follow up }\end{array}$ & $\begin{array}{l}\text { Studied in } 168 \text { patients } \\
1 \text { year primary endpoint }\end{array}$ & $\begin{array}{l}\text { Studied in } 101 \text { patients, } \\
1 \text { year primary endpoint, } \\
24 \text { m follow up }\end{array}$ \\
\hline $\begin{array}{l}\text { Specific } \\
\text { administration }\end{array}$ & $\begin{array}{l}\text { Subretinal injection after } \\
\text { vitrectomy under } \\
\text { anaesthesia, "Ocular GT } \\
\text { treatment center" }\end{array}$ & $\begin{array}{l}\text { "Qualified treatment centre", } \\
\text { apheresis, HSCT, } \\
\text { long-term follow up }\end{array}$ & $\begin{array}{l}27 \text { treatment centers } \\
\text { in the US (CureSMA) }\end{array}$ & $\begin{array}{l}\text { "Qualified treatment centre", } \\
\text { leukoapheresis, CRS } \\
\text { in } 58-77 \% \text { of patients }\end{array}$ & $\begin{array}{l}\text { "Qualified treatment centre", } \\
\text { leukoapheresis, CRS } \\
\text { in } 58-77 \% \text { of patients }\end{array}$ \\
\hline
\end{tabular}

Fig. 2. Selected $5^{*}$ gene therapies that have been approved in the EU/US to date.

A gene therapy for SMA, Novartis' Zolgensma (onasemnogene abeparvovec), has been approved in the US at a list price of USD 2.1 million, and the EMA recommended its conditional approval in March, with a request for additional data on long-term safety and efficacy by 2025 [14].

France is now reimbursing Takeda's cell therapy Alofisel (darvadstrocel) for Crohn's disease in hospitals, at EUR 54,000.

Janssen's adeno-associated virus-RPGR gene therapy for the inherited retinal disease $\mathrm{X}$-linked retinitis pigmentosa has received priority status for assessment from the European Medicines Agency under the PRIME scheme [15]. And other upcoming ATMPs include BioMarin's haemophilia A gene therapy Valrox (valoctocogene roxaparvovec), GenSight Biologics' GS010 for Leber hereditary optic neuropathy, and Audentes Therapeutics' AT132, a drug for X-linked myotubular myopathy [16]. Orchard therapeutics is also expected to file an application in Europe for OTL-200, its single-dose gene therapy for metachromatic leukodystrophy [17].

There are an estimated 450 companies across the globe working on the development of gene therapies, and 205 of those have narrowed their focus on rare diseases. The number of companies working more broadly on regenerative medicine (including gene therapy, geneedited cell therapy, cell therapy, and tissue engineering) are estimated at 900, of which a third are in Europe. There were more than 1,000 clinical trials underway worldwide by the end of 2018 (mainly in gene therapy and gene-modified cell therapy, with fewer in cell therapy and only some dozens in tissue engineering), and these included 92 in Ph III, 595 in Ph II, and 341 in $\mathrm{Ph}$ I. Global financing raised for the sector in 2018 is estimated at EUR 13 billion, 73\% up on 2017 [18].

Now the expectation is that some 20-30 new ATMP filings will be made in Europe annually over the next 5 years. Preclinical work is underway on solid tumours with autologous mesothelin-targeting CAR-T. So rapid is the acceleration in the UK that the country's Cell and Gene Therapy Catapult has expressed concerns over how the sector will meet its demands for specialised staff. It estimates that the UK's cell and gene therapy industry's current 3,000 jobs (up from 500 in 2012) will rise to 6,000 by 2024 as more therapies move toward commercialisation, with high demand for manufacturing and bioprocessing roles [19] (Fig. 2). 
Horgan et al.: Propelling Healthcare with ATMPs

\section{The Challenges}

Yet, there are numerous challenges facing the sector, complicating the translation from research into patient access. The performance of ATMPs still needs to be optimised. Gene therapy has yet to deliver fully on its promises for patients. There are scientific, clinical development and regulatory issues that hamper development of the sector, including inadequate understanding of the way the products act/react in the body, the need for robust and predictable manufacturing processes that can produce products that are fit for the patient in either an individualised way or in a "very small populations" way, a strong correlation between the knowledge of the product and the safety profile and clinical benefit (including RWD in the post approval space), and the ability to reduce cost [20].

In contrast to innovation with new chemical entities or biologics such as antibodies and vaccines, ATMP development involves substantial scientific and technical uncertainties, compounded by limited experience with clinical and commercial use, and difficulties for SMEs in accessing funds. The value proposition for these treatments is also complex and challenging to justify for healthcare systems, as the prices are often high, and the pharmacoeconomic evaluation requires a paradigm shift in approach [21].

EMA's own recently published regulatory strategy for 2025 spelled out the challenges: "The number of applications for approval has been very limited," and "despite ongoing efforts in this area, more remains to be done to address current challenges and those that will rise from emerging technological advances in the ATMP field" [2].

Legislation has evolved over two decades both to promote the sector's potential and to safeguard the public. The basic EU rules on pharmaceuticals dating back to 2001 have been updated to cover the advancing science and technology. Under EU legislation, stem cells are categorised as ATMPs when these cells undergo substantial manipulation or are used for a different essential function. They can be somatic-cell therapy products or tissue-engineered products, depending on how the medicine works in the body [22]. The EU classifies three main types: gene therapy medicines, somatic-cell therapy medicines, and tissue-engineered medicines. In addition, "combined" ATMPs may contain one or more medical devices as an integral part of the medicine, such as cells embedded in a biodegradable matrix or scaffold (detailed definitions are set out in Regulation (EC) No. 1394/2007 and Directive 2001/83/ EC) $[23,24]$.

Since 2011, the EU's centralised authorisation procedure for medicines has been adapted with defined and customised technical requirements for ATMPs, and specific - and strict requirements relating to risk management and traceability (including retaining data for a minimum of 30 years after product expiry). EMA conducts the single evaluation and authorisation procedure and continues to monitor safety and efficacy. A specialist Committee for Advanced Therapies provides the scientific assessment in a draft opinion on a product's quality, safety and efficacy that it transmits to the EMA's Committee for Medicinal Products for Human Use, EMA's main scientific body, which produces a recommendation as the basis for the European Commission to make the final decision. The CAT also makes recommendations on the classification of ATMPs, gives scientific advice, and advises on efficacy follow-up, pharmacovigilance, and risk management systems. It also organises meetings and workshops with experts and stakeholders - including on genome editing technologies, adeno-associated viral vector-based gene therapy, and genetically modified cell-based cancer immunotherapies $[25,26]$.

In addition to its obvious intention of guaranteeing the highest level of health protection for patients, the EU legislation was designed explicitly to ease access to the entire EU market, to ensure wide availability of approved products, and to promote the competitiveness of European companies in the field.

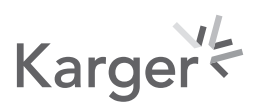


But an official review of the ATMP regulation in 2014 concluded that while it had protected patients from unsound treatments, it found shortcomings across manufacturing, early and later phases of development, the marketing authorisation process, and the post-marketing setting. The EU response was to confirm that it was committed to supporting the development of ATMPs and was determined to "ensure that the regulatory framework supports - and not hinders" their development [10]. This response took concrete shape with an EU action plan agreed in 2017 (and updated twice in 2018), aimed at streamlining procedures and meeting developers' specific requirements more smartly [27]. Efforts have also been made by regulators to reduce administrative burdens and adapt manufacturing requirements to the specific characteristics of ATMPs: a specific GMP framework for ATMPs was created, and EMA organised specific training sessions for national inspectors to align their approaches. An updated guideline on "Quality, preclinical and clinical aspects of gene therapy medicinal products" (EMA/CAT/80183/2014) was published in 2018, and work got underway on guidelines on quality, non-clinical and clinical requirements for applications for clinical trials for ATMPs, and on quality, non-clinical and clinical aspects of medicinal products containing genetically modified cells, as well as on adapted guidance on Good Laboratory Practice for ATMPs. An EMA Q\&A on the risk-based approach for ATMPs that have not been subject to substantial manipulation was published in 2017 to explain how this can provide flexibility and reduce requirements for a marketing authorisation application depending on specific risks. And 2018 saw an update to the procedural advice on evaluation [28] and a draft revised guideline on safety and efficacy follow-up and risk management [29]. And it took 12 years, but the European Commission published in 2019 the guidelines on good clinical practice specific to ATMPs that it was mandated to produce back in 2007. Approval of clinical trials for ATMPs remains a national competency, and some EU-level guidance has long been felt to be lacking [30].

While legislation and regulation may serve to limit and control risk and to maintain standards, there are many outstanding challenges that the authorities do not - yet, and perhaps never will - resolve. Surveys of the European sector have highlighted some major hurdles across the broad range of ATMP activity.

The complexity of products such as CAR-T cell therapies means that their translation from basic and pre-clinical research to clinical trials poses many challenges that slow down clinical development. In preclinical development, the needs identified include more access to molecular imaging, greater certainty over the right models and over the criteria for robust preclinical assessment, insufficient information on immunogenicity, and imprecision over quality standards. Good predictive safety models for ATMPs in general and for cell therapies in particular are also lacking.

In clinical development, problems arose from the inevitably small size of trials, the disease dependence of clinical trial designs, the need for long-term monitoring of patient and socio-economic impact, and the lack of funding for trial design and implementation [31].

Safety remains a critical challenge for gene therapy. In May 2020, one child died from sepsis and two others suffered severe side effects in a clinical trial of AT132 run by Audentes Therapeutics, and in June 2020, one of these two children suffering from side effects had also died. The gene therapy AT132 is designed to treat X-linked myotubular myopathy, a deadly disease caused by mutations in a single gene. All these three children had high doses of AT132, and the clinical trial has been officially put on hold [32].

Manufacturing presents a wide range of challenges. It suffers from a lack of robust potency assays for ATMPs, supplies of new materials such as cells and vectors, the heterogeneity of product types (viral/non-viral; cells; nucleic acids; other biologics etc.), and the lack of pharmacopoeial monographs for pharmaceutical grade raw materials. The materials are not "industrialised," and there is no established "standard" for them.

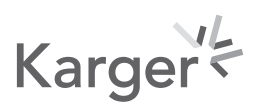


In manufacturing at scale and with consistency, there is a lack of common best practices and "automated" production platforms that hinders the translation of therapies to real, costeffective commercial products. The quality and supply of the raw materials suffers from variable levels of purification following production, influencing functionality and stability. High variability of starting material particularly affects autologous cell therapies. Where materials used in the process are "non-standard" and are supplied by non-industrialised suppliers, the consequences can be batch-to-batch inconsistency, and single sourcing issues. The challenges are amplified by the absence of an aligned quality framework tailored to the needs of single to small patient numbers, and scaled to control the risks to these patient populations, as opposed to scaled for large traditional pharmaceutical batch sizes. In general, there is a lack of manufacturing know-how, regulatory sciences, and Current Good Manufacturing Practice (CGMP) related to ATMP usage. There is a shortage of well-trained engineers and production and QC personnel that understand the manufacturing processes and are capable of developing automated/robotic methods and common platforms. Mature analytical technology/capability (beyond potency) that can adequately characterise the product is lacking.

Due to these deficiencies, new developments that would lead to a more consistent and reproducible manufacturing of ATMPs are in need of investment. For genetic therapies, the purification of the viruses is problematic and cumbersome. During an infection of the host cell not only infectious virus particles are produced, but also empty virus particles without genomes. More characterisation is required of the process of virus production at the cellular level to deliver high-quality infectious particles and limit the empty particles. Large-scale purification technologies to enrich the infectious virus particles in the final gene therapy product are not available. Qualified small-scale models are lacking, and the knowledge on formulation of the final product of a genetic therapy is restricted. This results in high production costs combined with considerable regulatory challenges and quality concerns. Many current manufacturing methods are developed at universities, hospitals or in SMEs and are difficult to transfer/scale up to commercial processes that are needed for the market. Cost-effective processes are needed that guarantee high quality and safety of the products delivered. There are also uncertainties with respect to long-term effect (persistence) of each of these (cell therapies and gene therapies) and the role that re-treatment might play, even many years out, in the overall outcome for patients [18].

Once marketing authorisation is granted, decisions about price and reimbursement take place at the level of each member state in the context of the national health systems. On health technology assessment, pricing and reimbursement, and market access, major problems are frequently cited as a major barrier for ATMP developers, particularly in Europe where national approaches vary widely, and it is frequently argued that the consequences, in terms of delay, uncertainty, and limitations, require a systematic solution. There are differences with regard to acceptance of real-world evidence in HTA and pricing among European countries - requiring a shift in approach, especially for drugs with conditional approvals, orphan drugs or advanced medicinal therapy products (Fig. 3).

The use of real-world evidence of clinical utility is needed, as is education and training for health professionals, regulators, HTA experts, and payers. $60 \%$ of development of ATMPs is executed by research centres and hospitals - none of them with any commercial capability. There are difficult trade-offs in HTA between meeting the customary demands for head-tohead comparators and what is ethically possible, and between long-term follow-up requirements and costs. There are frequent calls for a modification to the way HTAs assess ATMPs, particularly before the next wave of gene therapies are approved. There is insufficient alignment between regulatory early access pathways and reimbursement pathways [33]. Adequate education is seen as an essential complement to the development and use of gene therapy, and the education has to extend beyond patients and clinicians to the entire

\section{Karger'}




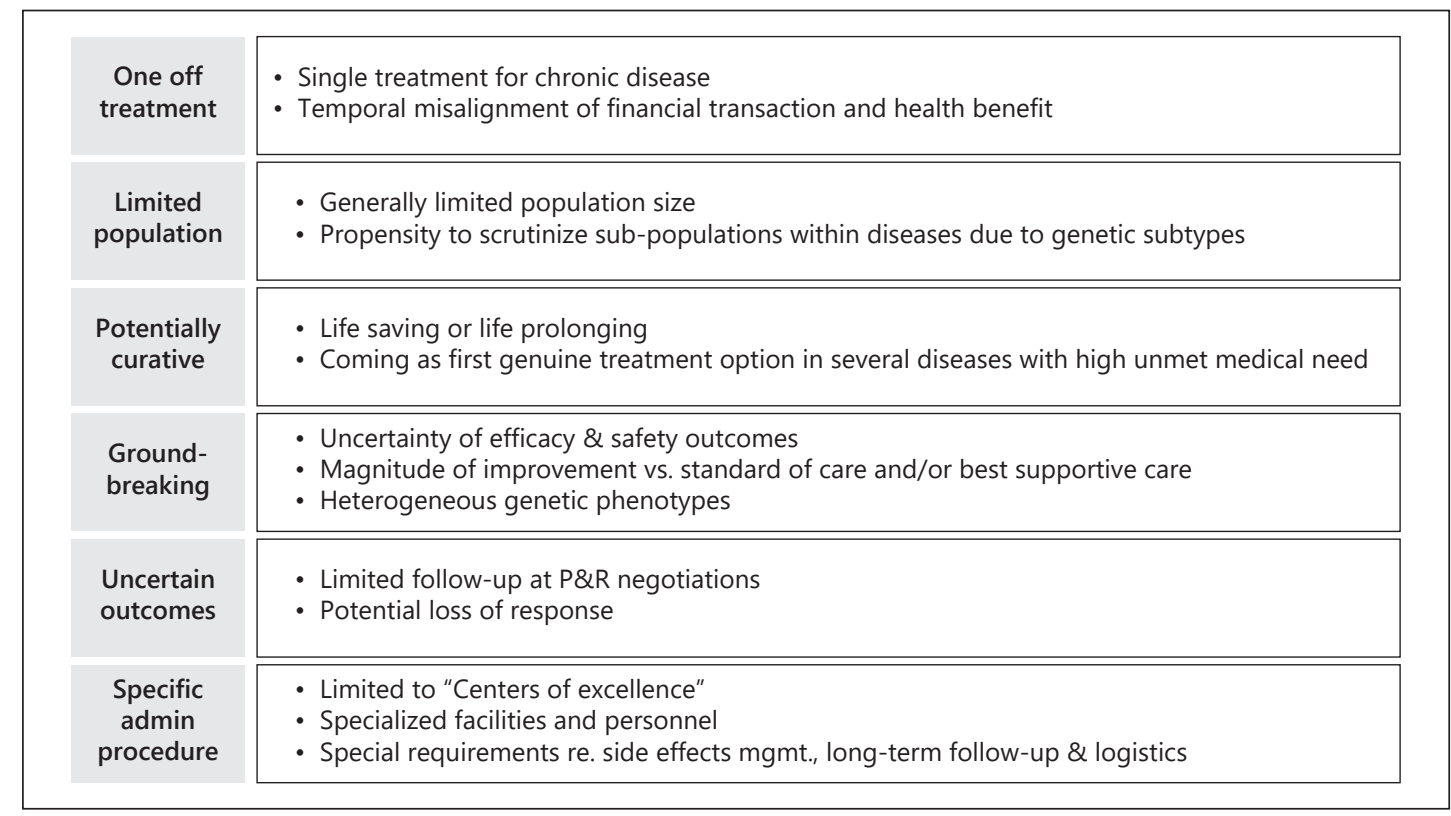

Fig. 3. Specificity of gene therapy.

community, with an alignment of the knowledge base on the current scope (and limitations) of gene therapy. Well-informed medical professionals are indispensable - but so too are wellinformed commissioners of and payers for gene therapy, and well-informed carers of patients who might benefit.

Market withdrawals of authorised ATMPs show that a sustainable business model still has not emerged, according to pharma executives from companies that have taken authorised drugs off the market. MolMed's cell therapy Zalmoxis was approved conditionally in the EU in August 2016 for patients with high-risk haematological malignancies who have had haploidentical haematopoietic stem cell transplants, but was overtaken by the pace of advances in the transplant field. The company admitted it had taken too long to bring the therapy to the market, and bone marrow transplantation moved on faster [3]. Chiesi, which owned the commercialisation rights to Glybera (alipogene tiparvovec), but ceased marketing it, said the system is not sustainable, and especially true for rare diseases "where the business model just does not add up" [34].

NICE's programme director of scientific affairs Nick Crabb says the uncertainty surrounding gene therapy efficacy and long-term durability will likely "be with us for a long time," and more experience is needed with these products before they can confidently be considered curative. German health insurance agency GKV-SV has urged the application of retroactive pricing to all ATMPs [35].

There are tensions over the provision within the EU regulatory framework to treat patients with ATMPs in the absence of a marketing authorisation under a so-called hospital exemption (HE) designed to cater for a limited number of patients, to facilitate early access of new treatments in case of unmet medical needs. A HE can be granted when the product is prepared on a non-routine basis according to specific quality standards and used in a hospital under the exclusive professional responsibility of a medical practitioner. There are longstanding concerns among European manufacturers of advanced medicines that this exposes them to unfair competition. They point out that national interpretations of this provision vary, and that a lack of GMP facilities in hospitals jeopardises quality standards for these 
products. They are not equivalent to centrally authorised advanced medicines, says industry, citing "the risk unlicensed products may pose to patient safety," because the innate complexity of ATMPs means that "even slight differences in molecular structures, in the cellular composition of the final products, or in the different manufacturing steps that are necessary to ensure consistent high-quality products" can have a major impact on their clinical profile and performance [36]. "Substantial differences in their product characteristics have the potential to drive variation in quality, safety and/or efficacy," says a recent EUCOPE statement: "It is not in the best interest of patients to substitute a centrally authorised ATMP with a less rigorously tested hospital exempted ATMP that has not gone through a robust quality/safety/ efficacy assessment." The exemption can dilute regulatory oversight and disincentivise private investment, and if misused could be a threat to innovation and protection of intellectual property, they argue, urging harmonisation across the EU. They say use of these exempt products should be permitted only when there are no centrally authorised ATMPs or clinical trials available in a member state for the product's indication. Their use "should be medically justified, and it should be demonstrated that an authorised ATMP or medicinal product or clinical trial with an ATMP for the same indication would not be suitable for the patient," EUCOPE urges in the face of what it sees as the growing number of unregulated applications of HE, which do not require the long and costly safety, quality, and efficacy demonstrations that industry is subject to [37].

Regulators themselves have faced difficulties in reaching decisions. The EMA's assessment of alipogene followed protracted deliberations in which the file was examined and voted on four times, and the conventions - if not the rules - governing EMA procedures were all but thrown out of the window. The EMA rejected its approval despite a favourable recommendation by the specialist CAT committee, demonstrating the need for clarifying the relationship between Committee for Advanced Therapies (CAT) and Committee for Medicinal Products for Human Use (CHMP), and for some greater recognition that many issues in the regulatory dossier of ATMPs require specific understanding of gene and cell therapy products in addition to a robust general knowledge of the issues of traditional pharmacology. CAT members themselves maintain that the rapidly evolving field of gene therapy needs an integrated approach [34].

And national regulators' approaches can vary. The FDA has a reputation for quickly taking control of applications and tending to dictate how the sponsor should progress it. Germany's drug regulator, BfArM, has been accused of being "bureaucratic" because of the 16 different states it represents. France's drug regulator, ANSM, is characterised as "riskaverse" - a trait echoed in most European states, say some commentators, which can lead to sponsors facing not just one or two questions back about a drug application, but multiple pages of questions. Success will depend on the attainment of a more global approach - with agreement on aspects as diverse but fundamental as criteria for approval, conditions for patient follow-up, practices for data collection, and standards for outcomes.

Brexit has added to the challenges for ATMPs - as for so many other aspects of European life. The administrative difficulties arising from the forced relocation of EMA from London meant that work on more than 100 guidance documents had to be put on hold - including the guideline on the comparability for ATMPs, which was intended to address a recurrent issue for almost all ATMP developments where manufacturing changes take place during the product development. In addition, the development of gene and cell therapy - in which the UK is a leading force in both basic science and clinical translation - is faced with unhelpful uncertainty over its future relationship with EU-funded science [38] (Fig. 4).

And there are numerous intrinsic scientific questions that require elucidation. Currently, it is very difficult to know which patients will respond well to an advanced therapy and which will experience serious side effects. T cells are an important part of the immune system, and in recent years scientists have succeeded in creating "engineered" T cells designed specifically

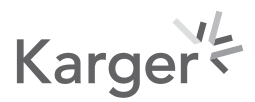




\begin{tabular}{|c|c|c|c|c|c|}
\hline Items & France & Germany & Italy & Spain & UK \\
\hline $\begin{array}{l}\text { Authority } \\
\text { involved }\end{array}$ & $\begin{array}{c}\text { Agence nationale de securite } \\
\text { du medicament et des } \\
\text { produits de sante (ANSM) }\end{array}$ & $\begin{array}{c}\text { German Federal Institute for } \\
\text { Drugs and Medical Devices } \\
\text { (BfArM) and the Paul-Ehrlich } \\
\text { Institute (PEI) }\end{array}$ & $\begin{array}{c}\text { Agenzia Italiana del Farmaco } \\
\text { (AIFA) } \\
\text { Law 648/96 }\end{array}$ & $\begin{array}{l}\text { Spanish Agency of Medicines } \\
\text { and Health Products (AEMPS) }\end{array}$ & $\begin{array}{l}\text { Medicines and Healthcare } \\
\text { Products Regulatory Agency } \\
\text { (MHRA) }\end{array}$ \\
\hline Overview & $\begin{array}{l}\text { - The conditions for ATU: } \\
\text { specialties are to treat, } \\
\text { prevent or diagnose serious } \\
\text { or rare diseases } \\
\text { - No proper treatment } \\
\text { - Efficiency and job security } \\
\text { are presumed as per the } \\
\text { scientific knowledge } \\
\text { - Also, there are two types of } \\
\text { ATU: Cohort ATU - for a } \\
\text { group or sub-group of } \\
\text { registered patients } \\
\text { - ATU - nominative - for } \\
\text { named single patient }\end{array}$ & $\begin{array}{l}\text { Medicinal products for human } \\
\text { use can be used for specific } \\
\text { groups of patients without } \\
\text { marketing authorization or } \\
\text { previous approval in } \\
\text { Germany }\end{array}$ & $\begin{array}{l}\text { - An unauthorized medication } \\
\text { can be included by AIFA in } \\
\text { the official list to be } \\
\text { prescribed at the NHS charge, } \\
\text { if it is for a specific disease } \\
\text { with no therapeutic choice. } \\
\text { Three types of medications } \\
\text { that can be included are: } \\
\text { Innovative drugs authorized } \\
\text { for sale abroad, but not in } \\
\text { Italy } \\
\text { - Unauthorized drugs which } \\
\text { underwent clinical trials } \\
\text { - Drugs to be used for a } \\
\text { therapeutic indication } \\
\text { different from those } \\
\text { authorized }\end{array}$ & $\begin{array}{l}\text { - CUP exists in Spain, } \\
\text { facilitating access to } \\
\text { medicines under } \\
\text { investigation as per the } \\
\text { EU definition for } \\
\text { compassionate use through } \\
\text { temporary authorization } \\
\text { - Both individuals and cohorts } \\
\text { benefit. The regulations and } \\
\text { process for CUP are well } \\
\text { defined } \\
\text { - The companies decide to } \\
\text { supply free of charge or not, } \\
\text { based on which negotiations } \\
\text { happen }\end{array}$ & $\begin{array}{l}\text { The MHRA launched early } \\
\text { access to medicines scheme } \\
\text { (EAMS) scheme in April } \\
2014 \\
\text { - MHRA gives a scientific } \\
\text { opinion on the benefit/risk } \\
\text { balance of the medicine, as } \\
\text { per the data when the EAMS } \\
\text { submission is made. The } \\
\text { opinion lasts for a year and } \\
\text { is renewable }\end{array}$ \\
\hline
\end{tabular}

Fig. 4. Mechanisms in EU5 markets for earlier access for patients with high unmet need.

to fight cancers. However, when developing T cell therapies, it is very hard to predict serious toxicity issues, and it is also hard to estimate accurately how well a treatment will work. There are challenges with CAR-Ts: their association with unique, specific, and acute toxicities. And there are challenges in production of engineered T-cell therapies in line with good manufacturing practice. And for all their current success in the haematological malignancies space that CAR-Ts are currently approved for, they have been less effective in solid tumours.

There are gaps in the current understanding of viral-mediated gene therapy and cell therapy, which hold up progress with advanced therapy products in terms of biology and safety. Regulatory agencies have to consider theoretical concerns in this emerging field, largely due to a lack of supporting data and evidence [39].

There are wide gaps in patient centricity and patient perspectives in ATMP development, with a lack of registries or other systematic recording or collection.

Views on pharmacogenetics and gene therapy differ across European countries, but there are concerns over its use in less severe conditions and high levels of fear in its application to brain conditions over sufficient prior information. And in the area of ethics, germline gene therapy's potential for correcting and eliminating genetic deficiencies at the developmental stages of a cell raises issues of genetic enhancement beyond the therapeutic applications of this technology. Public concerns have been noted over the ethics of enhancement, particularly in relation to access, and to discrimination. It may be necessary to incorporate effective public debate over social and ethical concerns into a regulatory process which is primarily concerned only with the efficacy of new technologies [40].

\section{Some Solutions}

The development and production of cell-based therapies, tissue engineering, and gene therapies feature prominently in the current IMI strategic research agenda, along with establishment of regulatory pathways and frameworks and payer framework to support the authorisation of new medicines [41]. 
A EUR 30 million project on accelerating research and innovation for ATMPs will aim to boost understanding of the factors that trigger an immune response to ATMPs, and develop tools to study them. Working with regulators, it will aim to ensure the tools and data generated are in line with what regulators need to assess ATMPs. The topic will focus on rare diseases caused by a single gene mutation, but many of the findings will be applicable to other diseases.

A EUR 17.5 million project on the development of engineered T cells to fight cancer will aim to predict serious toxicity issues and how well a treatment will work. Other projects aim at developing pre-clinical models to better predict safety and efficacy in CAR-T therapy, with a regulatory frame for the translation of pre-clinical findings into the clinic, and standardised monitoring methods for predicting product immunogenicity in humans, to improve understanding of gene/cell therapy drug metabolism inside a host. Standardisation of analytical procedures could also improve comparability of CAR-T-cell batches [42].

It is not appropriate to speak of a "guarantee" of quality or safety of these products because the mechanism of action is complex and poorly understood, and effectiveness relies on harnessing innate attributes of the body's physiology (immunology, or nucleic acid repair, and division) in the face of the reality that each patient is different. There are no good animal models for safety assessment of these products. The side effects are poorly understood, and the characteristics of the product that cause these side effects are not well characterised. In addition, viral vectors as gene editing tools have the potential to damage the target cells where they initially enter and insert the repair. This can cause organ/tissue damage and can even lead to death. Pre-existing immunity to the viral vectors can prevent incorporation of the repair due to the immune clearance of the vector before reaching the target cells. It will require years to assess attributes such as persistence of an intended in vivo gene therapy.

On manufacturing, the Innovative Medicines Initiative (IMI) will aim to conduct research into flexible and cost-effective processes to maximise quality and safety, and develop simple and robust analytical tools to assure controlled and safe production, including effective methods to detect and prevent adventitious agent contaminations. It will develop vaccine and protein formulation and investigate excipients that increase stability, especially with regard to proteins and the new and complex multivalent vaccines, in order to allow a unified regulatory approach accepted by global health authorities.

To achieve sustained therapeutic efficacy in gene therapy, it will conduct research into countering risks around the persistence of the effect and re-dosing the vector, so as to allow treatment of broader populations.

Specifically for ATMPs, IMI projects are planned to develop closed and automated production systems, and highly sensitive analytical tools/methods for increased scale and improved robustness of manufacturing processes. A further objective is to foster progress of manufacturing know-how, and to provide education related to ATMP acceptance and reimbursement and good manufacturing practice. This is intended to promote "a fully-fledged industrial activity to make the EU more competitive and make advanced therapy products available to all patients in need" [43] (Fig. 5).

An important contribution to gene technology evolution could come from IMI through focused development efforts in data platforms to allow correlative analysis across product attributes and patient outcomes. This has potential for driving innovation based on data that demonstrates what is important for safety and efficacy of these products.

Public/private partnerships with institutions that look at promising products and industry sectors offering new technology and capacity would help in this field where technology is changing so rapidly - rendering the technology used in the development of Kymriah and Yescarta outdated. It would also be valuable if they could promote a move from the traditional form of regulation to a framework where the process is reviewed and "versioned" at

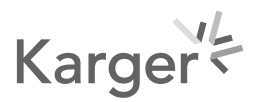




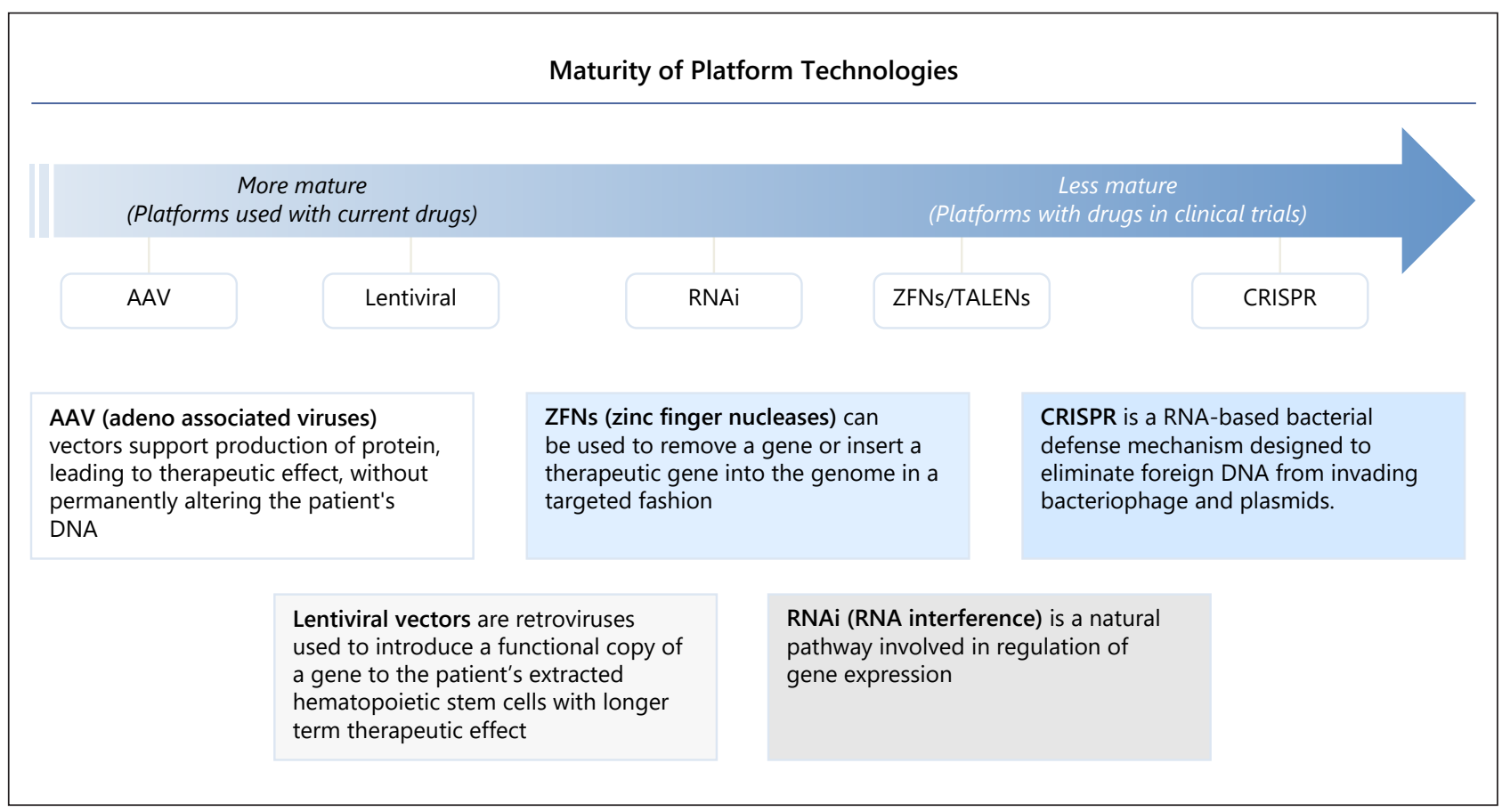

Fig. 5. Platform technologies which are being utilised for gene therapy.

the technology level, and the product is reviewed and evaluated on the health benefit it brings to patients.

The new guidelines on clinical trials rules for ATMPs, now in force, confront the issues of manufacturing constraints and short shelf-lives, or where the mode of application makes placebo controls difficult. In line with the growing regulatory recognition of the importance of real-word data, the guideline also openly states that "the long-term effects of the product may require specific arrangements for long-term follow-up of the subjects," and "it is recognised that it may not always be feasible to generate relevant non-clinical data before the product is tested in humans." The choice of study population should consider whether the potential risks of the ATMP are less favourable than with existing alternative approaches, particularly in long-lasting or irreversible treatments. For trials with paediatric subjects, prior studies in adults should be performed unless the condition is life-threatening, and for populations that might ultimately be amenable to transplantation, sponsors should consider whether exposure to the ATMP potentially compromises future transplant success. Special caution should be exercised in cases of life-threatening diseases, where there is a risk that trial subjects may not survive until the administration of an investigational medicinal product that requires long manufacturing periods. The end of the trial should be defined without ambiguity, because the mode of action, novelty, and scientific uncertainties in connection with ATMPs may require patients to be on long-term follow-up [44]. In addition to observing the EU guidelines agreed in 2017 on good manufacturing practice for ATMPs, sponsors should take account of the impact of the variability of donor- or patient-based starting material when defining release specifications for cell-based ATMPs (such as cell numbers or transduction efficiency). In autologous settings, the impact of the disease status of the patient on the quality of the starting material, and the potential variability of the final drug product, should be considered. In case of complex handling processes, sponsors should provide investigators 
with adequate training. For tissues and cells of human origin as starting materials, documentation should confirm that the donation, procurement, and testing are in accordance with EU rules and that a traceability system enables the bidirectional tracking of cells/tissues. Where an ATMP incorporates a medical device, full information must be provided on the characteristics, performance and intended use of the device, and whether it meets the safety and performance requirements under the EU's 2017 regulation. Full information on the product and its risks must be provided to investigators, including the potential consequences for a patient requiring further treatments for the targeted disease - since an immunoglobulin treatment later in life could impact on expression of the introduced gene by antibody interaction, for instance. Detailed information should be provided on product handling, containment and disposal, with the level of information "commensurate to the risks," particularly for ATMPs that contain infectious biological material, or a bacterial or viral vector with the potential for shedding. Where applicable, the subject should be informed of the irreversible nature of an ATMP, and of risks to close contacts and offspring, or if the treatment could compromise future pregnancies [45].

In terms of national regulation, some agencies are aiming at providing specific assistance. The UK's MHRA describes its job as to "guide [pharma] through the regulatory maze," and in recognition of ATMPs, it has set up an innovation office to advise on planned filings of ATMPs.

On reimbursement, increasing success is being found in identifying functioning models. Yescarta and Kymriah (list price for both around EUR 300,000) are authorised for their respective cancer indications in the EU5, and they have obtained reimbursement in several countries with a year, providing real-world examples to managing the data uncertainty and addressing the affordability challenges. Spain and Italy are demonstrating novel outcomesbased reimbursement to move beyond the more traditional reimbursement schemes and provide reward instead based on treatment success, with the deferred payments circumventing the customary annual budget cycle of healthcare payers and manufacturers. Italy uses registries in conjunction with managed entry agreements to provide a sustainable model to reimburse advanced therapies and to adapt the cost for each patient, on a payment-byresults basis - the model it used for Strimvelis.

Novartis/AveXis has received conditional approval for its gene therapy Zolgensma for SMA in the EU in May 2020, and will launch in Germany at a hospital price of EUR 1.945 million at select neuropaediatric centres, with the hope to reach a "smart deal" allowing UK patients access by the end of the year. To enable payer and health systems adapt to the innovative gene therapy with an extremely high price tag, Novartis/AveXis has designed and implemented a "Day One" access program to align the costs even before national pricing and reimbursement negotiation. This program provides several customisable options, including retroactive rebates, outcomes based rebates (the risk of tiered refunds of up to 100\%), training for healthcare professionals on the administration of the therapy and follow-up care, and access to a global SMA registry [46, 47].

In France and the UK, reimbursement for Yescarta and Kymriah is based on Coverage with Evidence Development, and future price and reimbursement reassessment will be based on a combination of both longer-term follow-up from the ongoing trials and real-world data from national clinical practice. In the UK, RWD is helping the uptake of CAR-T therapies via NHS England's national CAR-T clinical panel, a centralised process for establishing eligibility. NICE says that RWD is important to assess value for future ATMPs "since these products do not come with a body of evidence that NICE is used to" [48].

NICE has produced final guidance on eight ATMPs, seven of which are cell and gene therapies, and has issued positive recommendations for use in the NHS on most of them, although underlining that innovative payment models are needed to help timely patient access while data for ATMPs remain immature. NICE is reviewing Novartis' one-off gene therapy Zolgensma

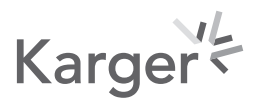


in 2020, and it has assessed Novartis/Spark Therapeutics' GBP 613,410 gene therapy Luxturna via its highly specialised technologies programme for treatments for very rare diseases [49]. The UK is also launching a GBP 500 million Innovative Medicines fund with a wider scope than the cancer fund it replaces [50].

In Germany, Takeda reached an agreement with umbrella payer group GKV-Spitzenverband for its cell therapy Alofisel at a hospital price of EUR 51,400, lower than its EUR 60,000 2018 launch price [51].

In the US, Spark has launched a "successful outcomes-based payment model," in which, payers can be eligible for rebates if the USD 850,000 treatment does not achieve certain visual ability as measured by an eye test [52]. Bluebird bio has developed a model based for Zynteglo on outcomes-based payments, in which five equal-based payments are spread out over 5 years [13]. It is looking to negotiate that "in the key markets within the EU, including the UK." There is also interest in what is described as "the Louisiana Netflix model," which acts as a subscription service, where a subscription to the manufacturer allows access to as much treatment as required for an indication [53]. There is a trend towards outcomes-based payment models, where reimbursement depends on achieving pre-agreed targets, based on data measurements co-produced by patients, clinicians, commissioners, and local government. Industry must be "open minded," according to Jim Thomson, Pfizer's senior manager for market access and gene therapy, as innovative payment models will be needed to support dozens of new ATMP filings in Europe every year, he predicts.

The atmosphere in Europe is sufficiently attractive for Gilead to open a new CAR-T cell therapy production facility in the Netherlands, able to produce 4,000 CAR-T cell therapies can be produced annually - a step forward in making CAR-T cell therapy available to eligible European patients, since previously each individual patient's cells were shipped to a facility in Los Angeles for treatment [54].

Much depends in all these approaches on the ability to furnish data. A project is now underway on ATMP patient registries of outcomes data and evidence may help. This aims to pilot the benefits of a holistic, pan-EU registry for a specific rare disease (e.g., Duchene muscular dystrophy; haemophilia) serving the needs of academia, scientific associations, industry, patient organisations and healthcare payers. It will also address the current gap in patient centricity and patient perspectives in ATMPs, which currently often go unrecorded. Once completed, the pilot could potentially serve as a model for other rare diseases and provide patients with better access to innovative medicines [55].

There are also tight safety requirements. A large proportion of ATMPs are developed for rare to ultra-rare disease, which has an impact on the type of clinical trials (often without control arm) and the size of the safety and efficacy database at the time of approval. It is a legal requirement to have a follow-up of safety and efficacy of ATMPs after approval: postauthorisation safety studies, and post-authorisation efficacy studies can be imposed for postauthorisation evidence generation of the ATMP. These studies can be observational, based on disease or product registries, but when registries are used as data source for such studies, there have to be case-by-case decisions on data elements, ATMP-specific data sets, data quality, consistency, accuracy, and completeness [56].

Access to treatment is seen as a key objective, but alongside is the recognition that access can come at a cost to health system budgets. Many issues around pricing and reimbursement remain open, leaving questions of patient access unresolved. Experts consulted in the development of this paper urged greater creativity in this field. The option of payment by results is confronted by the difficulty of agreement over calculations of benefit to societies. The role of health technology assessment bodies remains under discussion in Europe, in the absence of an EU-level agreement on coordination (and acceptance) of joint assessment, and on the distinction between HTA and national pricing and reimbursement processes. Without a

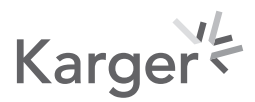


deeper understanding among HTA bodies of the potentially transformative impact on patients of the cure that some gene therapy could offer (and of the potentially beneficial economic impact on health systems...), the concern persists among developers that the opportunity cost of declining reimbursement is also unappreciated.

The value-based pricing model that has frequently been advocated by research-based companies, where the price of the therapy is estimated as a measure of the value it brings to patients and society, is seen as inadequate by many commentators, who fear it leaves health services vulnerable to high price demands, particularly for single-source products. Alternatives aimed at imposing controls, including "reasonable pricing" (based on demonstrated research and manufacturing costs), or sharing information among national authorities on actual prices paid, have yet to find universal favour or demonstrate their feasibility. One suggestion for action to secure reasonable pricing of gene therapy products is to incentivise gene therapy companies by an appeal to corporate social responsibility principles [57]. This envisages action by payers to encourage companies to create ad hoc subsidiaries for gene therapy products, gaining official status for the pursuit of social goals in parallel to the classical pursuit of shareholder value. By acquiring this form of legal status, companies should be able to leverage the social impact of their pricing in their performance indicators, thus affording them the opportunity to bring their pricing down to a "market-consistent" level in order to enhance their social performance, the authors recommend. A further step would be for payers to make reimbursement of gene therapy products conditional on their commercialisation by companies certified as having this status.

Other views of pricing and payment mechanisms were proposed by ICER (source: ICERGene-Therapy-White-Paper), including outcomes-based agreements, reinsurance, and various modes of payment amortisation. But ICER recognised the challenges of generating the sort of robust clinical evidence needed by decision-makers when only very small patient populations are involved, complicated by the novel aspects of gene therapy. The clinical gains offered by potential "cures" will be difficult to value when, in the absence of long-term data, there is no guarantee of long-term safety or of the durability of clinical benefit. So, agreement will be needed on how to make clinical trials that can offer real guidance for decision-making by payers and other authorities - as well as by clinicians.

ICER insists that to sustain future innovation in gene therapies while managing concerns regarding affordability, all stakeholders - manufacturers, payers, patients, and policymakers - will need to take vigorous and collaborative action to establish clear outlines for a comprehensive approach to evidence generation, assessment, pricing, and payment. It recommends early dialogue between manufacturers, payers and regulators on outcomes, trial design, postapproval studies, target population size, patient eligibility and the role of the therapy within the care pathway, approved treatment centres, and the agreed criteria for calculating value. It also urges the creation of patient registries for collection of real-world evidence. It recommends manufacturers to be ready with concrete proposals for financing any amortised payment system they might propose. And it urges payers to upgrade their information base and develop categories of gene therapy so as to tailor policies according to distinctive types of therapy.

\section{Consolidating Nascent Success into a Better Healthcare System}

The challenge now is how to make these 21st century breakthroughs available quickly, widely, responsibly, and in an economic context consistent with health system sustainability and an innovation-friendly climate. This requires a critical look at current legislation and the current systems for product assessment and funding. There will also have to be a careful

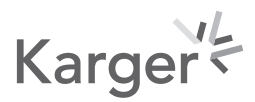


selection of disease targets linked to the vector systems available. And to do that will have to involve collaboration among all stakeholders: governments, doctors, insurers, patients, and pharmaceutical companies.

There are already positive signs of an improving climate and a more coherent approach. The CAT work plan for 2020 gives some concrete indications. In terms of pre-authorisation activities, it plans to finalise the revision of its guideline on quality, non-clinical, and clinical aspects of medicinal products containing genetically modified cells, after external consultation and in collaboration with the BWP. And it will finalise the development of a guideline on quality, non-clinical and clinical requirements for applications for clinical trials for ATMPs after external consultation. Its post-authorisation activities include timely implementation of registries and post-authorisation studies for ATMPs - and CAT will co-ordinate with existing EMA initiatives relating to registries and cross-committee collaboration including Pharmacovigilance Risk Assessment Committee (PRAC) and CHMP, and provide a framework for optimising regulatory requests for registries, so that requests are feasible, and study designs are capable of answering a specific safety/efficacy question.

CAT will also reflect, in collaboration with EMA, on how to enhance regulatory support on safety studies and registries during product development (e.g., via PRIME/Scientific Advice), and ensure, in collaboration with PRAC, that protocols are evaluated during the marketing authorisation procedure, and contribute to the development (by CHMP) of guidance on best use of and standards for registries for regulatory purposes. This will also take into account existing guidance, engagement with patient registries, and interactions with HTAs.

And crucially, it will set up a COMP-CAT working group to optimise the interaction and output of the two Committees in assessment of orphan ATMPs, and a PDCO-CAT working group to optimise the interaction and output of the two Committees in development and assessment of paediatric ATMPs [58].

The implications of the (now-delayed) implementation of the new medical device/in vitro diagnostics regulations on ATMP development will also be reviewed, with a CAT medical device focus group to follow implementation, and with a possible updating of the procedural advice on the evaluation of combined ATMP and the consultation of Notified Bodies. Thought will also be given, in collaboration with EMA, to enhancing regulatory support via PRIME/ Scientific Advice on MD/IVD-related aspects during product development, and training will be arranged for CAT members on MD/IVD [59].

Meanwhile, in parallel to the evolution of regulation and guidance, regulators are assisting the emergence of ATMPs in practical ways. EMA increasingly gives scientific support to developers in designing pharmacovigilance and risk management systems for ATMPs, through early dialogue with multidisciplinary or multi-stakeholder expert teams. EMA procedures for scientific advice are also being streamlined, including by strengthening interaction between EMA's committees with responsibilities for ATMPs. And increased interaction between EMA and EUnetHTA is underway on product evaluation, to increase understanding of health technology assessment, regulatory processes, and clinical added value of ATMPs. ATMPs are constantly on the agenda of the EMA-linked Innovation Task Force, a scientific, regulatory, and legal forum for early dialogue with applicants. The legislation also created incentives, including fee reductions for scientific advice and for marketing authorisation, with particular significance for smaller firms and for hospitals [60] (Fig. 6).

There are also encouraging signs in the broader EU context, despite the difficult circumstances of the coronavirus pandemic. The new EU health programme with its EUR 9.4 billion budget has among its top objectives to improve the availability of medicines, medical devices and other crisis relevant products, contribute to their affordability, and support innovation. And its own criteria for success will be measured by progress in access to centrally authorised medicines, in terms of number of orphan authorisations, ATMPs, paediatric medicines, and

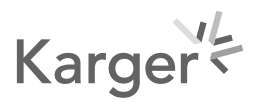




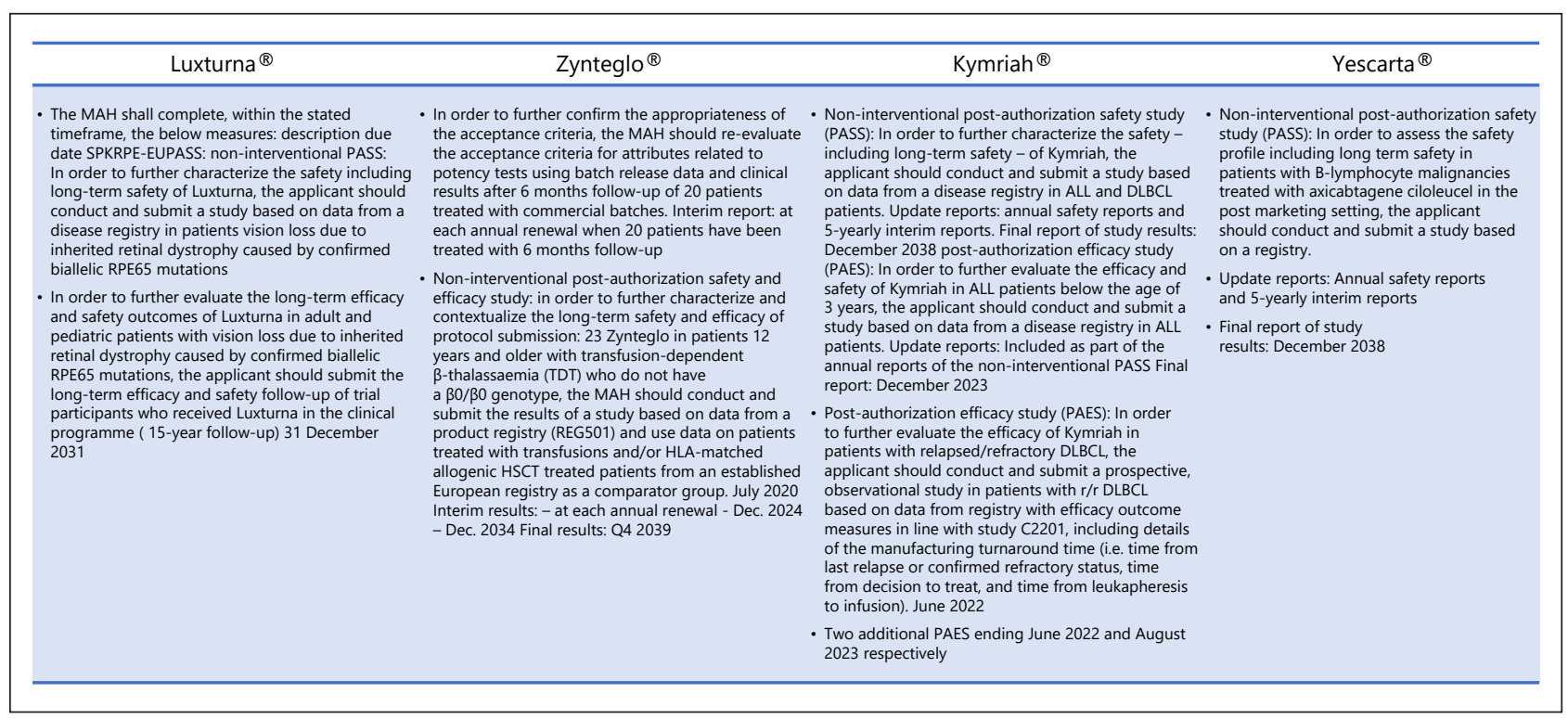

Fig. 6. Follow-up requirements of recently approved Gene Therapies in Europe - Outcome uncertainty led EMA to impose a systematic risk management plan to recently approved Gene.

vaccines for unmet needs. It will support clinical trials to speed up the development, authorisation, and access to innovative, safe and effective medicines and vaccines, support action to ensure greater availability of medicines, and support action to encourage the development of innovative products [61].

In the EU's new pharmaceutical strategy, announced for late 2020, procedures for accelerated development and assessment could be reviewed, particularly in light of the "opportunities brought by gene therapies and personalised medicine." And one of the questions posed in the consultation on the strategy focuses on the HE. "Certain medicines are developed based on genes, cells, or tissue engineering. Some of these products are developed in hospitals. These are covered by the notion of advanced therapy medicines. "Is the current legal framework suitable to support the development of cell-based advanced therapy medicines in hospitals?", it asks [62]. The pharmaceutical strategy could also become the forum for advancing the discussion of adequate manufacturing capacity in Europe - not just for active ingredients, but to produce valuable innovations.

Both the EU cancer mission now in preparation, and the EU beating cancer plan, on which consultation is also underway, are likely to add to the support for ATMPs, in view of their growing role in oncology.

And the EU is showing a new degree of regulatory pragmatism in the face of the COVID-19 disruption, with greater flexibility being exercised over administrative arrangements in the conduct of clinical trials during the crisis, and accelerated procedures for product authorisation - down from 9 weeks to 1 week for paperwork. It is also responding to the urgency of the pandemic challenge by easing state-aid rules for researching therapies and preventive measures, and even investing directly in vaccine manufacture, both via its advance purchase agreements, and in its support for a European vaccine candidate from BioNTech, with EUR 100 million from the European Investment Bank for its development programme with mRNA vaccines [63]. And it plans to circumvent the delays in meeting environmental risk assessment for coronavirus vaccines based on attenuated viruses and viral vectors that fall under the definition of genetically modified organisms, 
and that would otherwise be subject to specific EU biotechnology legislation, with the risk of "significant delay, particularly for multi-centre clinical trials" that are needed to generate robust and conclusive data on COVID-19 vaccines.

ATMPs feature prominently in the reinforced EU-US collaboration on medicines, with senior officials from the Commission, EMA, and FDA acknowledging the "similar regulatory challenges on both sides of the Atlantic," and agreeing to encourage early parallel scientific advice and to strengthen collaboration on common scientific approaches on regulation [60].

Additional assistance may emerge in the shape of the (also delayed) 2014 regulation on clinical trials, bringing more harmonised and swifter processes for approval of clinical trials.

And in terms of public support, despite the current complex regulatory regime there is a balance in favour, even of gene therapy, albeit laced with considerable uncertainty.

Within the manufacturing sector, there is growing interest in systems integration in production and distribution as the conviction grows that well-defined strategies will be critical for future standardisation and workflow optimisation.

Other areas of advanced investigation include small-molecule drugs that selectively control mRNA translation into proteins, plant micro-vesicles containing small RNAs in delivering and adjuvancy for sustainable cancer therapy, and developing the next generation of gene therapies, CRISPR-Cas9 technology, and engineered exosome therapeutics.

\section{Conclusion: A Seismic Shift in Healthcare Strategy}

ATMPs are improving the prospects for tackling severe disease - in many cases diseases that at present have no treatment - and the science and technology involved is intimately linked to Europe's broader development of new approaches to healthcare, dependent on early diagnosis and more personalised healthcare. Their emergence has been slow but is now showing undreamt of promise. The continued development of ATMPs now holds out the prospect of a significant evolution in Europe's ability to tackle healthcare challenges. It also promises to build Europe's scientific, industrial, and competitive strength in a global context.

The EU is itself in constant evolution, both organically, as its competences are progressively refined, and in response to changes in the world it inhabits. In healthcare, its evolution is marked not only by the emergency of the COVID-19 pandemic, which has largely monopolised the attention of all the major EU institutions throughout most of the early months of the year, but also by the constant increase in morbidity, that now affects more than its ageing population. 2020, with the initiation of a European Health Data Space [64] and a new Pharmaceutical Strategy [62], as well as radical new responses to the coronavirus pandemic, is an appropriate moment also for Europe to give greater priority to realising the potential of ATMPs as an intrinsic element in an integrated health strategy. It would be an important signal of a change in policy that holds out the prospect of a radical transformation of care in coming years as the full benefits of ATMPs are felt.

\section{Recommendations}

\section{For All Stakeholders}

- Cooperate in exploiting the opportunities of ATMPs to make advanced therapy products available to all patients in need, and to permit a full-fledged industrial activity add to EU's prosperity and international competitiveness

- Engage in early dialogue with developers on potential products to map out expectations and requirements from the perspective of each stakeholder group 
- Collaborate in establishing clear outlines for a comprehensive approach to evidence generation, assessment, pricing, and payment for ATMPs

For EU

- Promote standardisation in testing guidelines, validation, usage, quality control, consistency, and outcomes measurement and long-term follow-up of ATMPs

- Promote cross-sectoral collaboration and interdisciplinary research to advance understanding of ATMPs

- Promote investment in basic and applied science to improve understanding of ATMPs

- Promote integration of ATMP research in clinical medicine

- Promote the development of patient registries for collection of real-world evidence

- Promote coordination of clinical trials

- Promote alignment between innovators, payers, governments, businesses, and societies on what constitutes therapeutic value of ATMPs

- Explore the prospects for reinforcing Europe-based manufacturing of ATMPs

\section{For EMA}

- Develop regulatory pathways for ATMPs

- Explore common ground in criteria for decisions on patient follow-up and reporting

- Adjust frameworks to permit early interaction between sponsors and authorities including health technology assessment bodies

- Speed up provision of scientific advice

- Accelerate procedures

\section{For Member States}

- Align national pricing and reimbursement pathways with regulatory pathways

- Develop innovative reimbursement and payment mechanisms to align outcomes with costs, and enable long-term follow-up and evidence generation to support future clinical research and development

- Develop and link clinical databases and registries and ensure interoperability at EU level too

- Work to maintain close links with UK scientists after Brexit

- Ensure training of HCPs in ATMPs

- Upgrade payers' information base on ATMPs and gene therapy

\section{For ATMP Developers}

- Devise and implement faster, more precise, and cleaner manufacturing processes

- Prepare concrete proposals for financing any payment scheme they might propose

- Set up specific manufacturing hubs and logistic networks to ensure timely and traceable supply chain

- Develop shared validated analytical tools

- Establish an industry-wide group to ensure adequate access to raw material supplies

- Deliver education specific to the ATMP business to authorities and the public

\section{Acknowledgements}

Special thanks goes to Mark W Skinner, Past President of the World Federation of Hemophilia and the US National Hemophilia Foundation and Declan Noone, President, European Haemophilia Consortium, for their valuable input. 
In addition, we would like to thank the members of the European Alliance for Personalised Medicine, the many experts for their work in this area and the Million European Genome Alliance+ (MEGA+).

\section{Conflict of Interest Statement}

The authors declare that they have no competing interests.

\section{Author Contributions}

D.H. conceived, built, and drafted the article with critical input from his co-authors, expert interviews, and the partners.

\section{References}

1 Yu TT, Gupta P, Ronfard V, Vertès AA, Bayon Y. Recent Progress in European Advanced Therapy Medicinal Products and Beyond. Front Bioeng Biotechnol. 2018 Sep;6:130.

2 EMA. Regulatory Science Strategy to 2025. Cited June 23, 2020. Available from: http://www.ema.europa.eu/ en/annual-report-2019/regulatory-science-strategy-2025.html

3 Gancberg D. Twenty Years of European Union Support to Gene Therapy and Gene Transfer. Hum Gene Ther. 2017 Nov;28(11):951-3.

4 Cavazzana-Calvo M, Hacein-Bey S, de Saint Basile G, Gross F, Yvon E, Nusbaum P, et al. Gene therapy of human severe combined immunodeficiency (SCID)-X1 disease. Science. 2000 Apr;288(5466):669-72.

5 Mullard A. EMA greenlights second gene therapy. Nat Rev Drug Discov. 2016 May; 15(5):299.

6 Aiuti A, Roncarolo MG, Naldini L. Gene therapy for ADA-SCID, the first marketing approval of an ex vivo gene therapy in Europe: paving the road for the next generation of advanced therapy medicinal products. EMBO Mol Med. 2017 Jun;9(6):737-40.

7 Boráň T, Menezes-Ferreira M, Reischl I, Celis P, Ferry N, Gänsbacher B, et al. Clinical Development and Commercialization of Advanced Therapy Medicinal Products in the European Union: How Are the Product Pipeline and Regulatory Framework Evolving? Hum Gene Ther Clin Dev. 2017 Sep;28(3):126-35.

8 Gruber K. Europe gives gene therapy the green light. Lancet. 2012 Nov; 380(9855):e10.

9 ten Ham RMT, Hoekman J, Hövels AM, Broekmans AW, Leufkens HGM, Klungel OH. Challenges in Advanced Therapy Medicinal Product Development: A Survey among Companies in Europe. Mol Ther Methods Clin Dev. 2018;11:121-130. Published 2018 Oct 11. doi: https://doi.org/10.1016/j.omtm.2018.10.003.

10 Detela G, Lodge A. EU Regulatory Pathways for ATMPs: Standard, Accelerated and Adaptive Pathways to Marketing Authorisation. Mol Ther Methods Clin Dev. 2019 Jan;13:205-32.

11 Seimetz D, Heller K, Richter J. Approval of First CAR-Ts: have we Solved all Hurdles for ATMPs? Cell Med. 2019 Jan;11:2155179018822781.

12 NICE backs NHS use of Novartis' gene therapy Luxturna. Cited June 23, 2020. Available from: https://www. pmlive.com/pharma_news/nice_backs_nhs_use_of_novartis_gene_therapy_luxturna_1300700?SQ ACTION=clear_design_name\&full=true

13 Bluebird prices gene therapy Zynteglo at €1.575M in Europe, to be paid over 5 years. Cited June 23, 2020. Available from: https://www.fiercepharma.com/pharma/bluebird-prices-gene-therapy-zynteglo-at-eu1575m-europe-to-be-paid-over-5-years

14 Novartis' gene therapy takes additional step towards EU approval. Cited June 23, 2020. Available from: https://www.biopharma-reporter.com/Article/2020/03/30/Zolgensma-receives-EU-positive-opinion

15 EMA PRIME status granted to Janssen's inherited retinal disease gene therapy. Cited June 23, 2020. Available from: http://www.pharmatimes.com/news/ema_prime_status_granted_to_janssens_inherited_retinal_disease gene_therapy_1327763

16 BioMarin's haemophilia gene therapy moves forward in the EU. Cited June 23, 2020. Available from: http:// www.pharmatimes.com/news/biomarins_haemophilia_gene_therapy_moves_forward_in_the_eu_1320879

17 Application Being Evaluated Under Accelerated Assessment. Cited June 23, 2020. Available from: https:// www.globenewswire.com/news-release/2019/12/02/1954630/0/en/Orchard-Therapeutics-Announcesthe-Filing-and-Validation-of-Marketing-Authorization-Application-by-European-Medicines-Agency-forOTL-200-for-the-Treatment-of-Metachromatic-Leukodys.html

18 Carvalho M, Sepodes B, Martins AP. Regulatory and Scientific Advancements in Gene Therapy: State-of-the-Art of Clinical Applications and of the Supporting European Regulatory Framework. Front Med (Lausanne). 2017; 4:182. Published 2017 Oct 26. doi: https://doi.org/10.3389/fmed.2017.00182. 
19 Accelerated demand for specialist skills in the UK cell and gene therapy industry. Cited June 23, 2020. Available from: https://ct.catapult.org.uk/news-media/manufacturing-news/press-release-accelerated-demandspecialist-skills-uk-cell-and-gene

20 Hanna E, Rémuzat C, Auquier P, Toumi M. Gene therapies development: slow progress and promising prospect. J Mark Access Health Policy. 2017 Jan;5(1):1265293.

21 Higham R. Imagining the future of cell therapies: clinical trials, innovation and the intersection of clinicalacademic and commercial visions. New Genet Soc. 2019;38(4):363-386. https://doi.org/10.1080/14636778 .2019.1642742.

22 Papaluca Amati M, Pignatti F, Nolte A, Amerasinghe N, Gustafsson D, Moulon I, et al. EMEA and Gene Therapy Medicinal Products Development in the European Union. J Biomed Biotechnol. 2003;2003(1):3-8.

23 Regulation (EC) No 1394/2007 of the European Parliament and of the Council of 13 November 2007 on advanced therapy medicinal products and amending Directive 2001/83/EC and Regulation (EC) No 726/2004. Cited June 23, 2020. Available from: https://eur-lex.europa.eu/LexUriServ/LexUriServ.do?uri=0J:L:2007: 324:0121:0137:en:PDF

24 Directive 2001/83/EC of the European Parliament and of the Council of 6 November 2001 on the Community code relating to medicinal products for human use (OJ L 311, 28.11.2001, p.67). Cited June 23, 2020. Available from: https://eur-lex.europa.eu/legal-content/EN/TXT/PDF/?uri=CELEX:02001L0083-20121116\&from=EN

25 EMA Committee for Advanced Therapies (CAT). Cited June 23, 2020. Available from: https://www.ema. europa.eu/en/committees/committee-advanced-therapies-cat

26 EMA Committee for Medicinal Products for Human Use (CHMP). Cited June 23, 2020. Available from: https:// www.ema.europa.eu/en/committees/committee-medicinal-products-human-use-chmp

27 European Commission DG Health and Food Safety and European Medicine Agency Action Plan on ATMPs. Cited June 23, 2020. Available from: https://www.ema.europa.eu/sites/default/files/documents/2017/ $10 / 20 /$ action-plan-advanced-therapy_en.pdf

28 EMA. Marketing-authorisation procedures for advanced-therapy medicinal products. Cited June 23, 2020 Available from: https://www.ema.europa.eu/en/human-regulatory/marketing-authorisation/advancedtherapies/marketing-authorisation-procedures-advanced-therapy-medicinal-products

29 EMA. Pharmacovigilance for advanced therapies. Cited June 23, 2020. Available from: https://www.ema. europa.eu/en/human-regulatory/post-authorisation/advanced-therapies/pharmacovigilance-advancedtherapies

30 Klug B, Celis P, Carr M, Reinhardt J. Regulatory structures for gene therapy medicinal products in the European Union. Methods Enzymol. 2012;507:337-54.

31 Narayanan G, Cossu G, Galli MC, Flory E, Ovelgonne H, Salmikangas P, et al. Clinical development of gene therapy needs a tailored approach: a regulatory perspective from the European Union. Hum Gene Ther Clin Dev. 2014 Mar;25(1):1-6.

32 Two patients die in now-halted study of Audentes gene therapy. Cited July 29 2020. Available from: https:// www.biopharmadive.com/news/audentes-gene-therapy-patient-deaths/580670/

33 Jönsson B, Hampson G, Michaels J, Towse A, von der Schulenburg JG, Wong O. Advanced therapy medicinal products and health technology assessment principles and practices for value-based and sustainable healthcare. Eur J Health Econ. 2019 Apr;20(3):427-38.

34 Moran N. First gene therapy nears landmark European market authorization. Nat Biotechnol. 2012 Sep;30(9): 807-9.

35 Strachan J. C\&G Therapy? That'll Do NICEly. The Medicine Maker. Cited June 23, 2020. Available from: https:// themedicinemaker.com/business-regulation/cg-therapy-thatll-do-nicely

36 Halioua-Haubold CL, Peyer JG, Smith JA, Arshad Z, Scholz M, Brindley DA, et al. Regulatory Considerations for Gene Therapy Products in the US, EU, and Japan. Yale J Biol Med. 2017 Dec;90(4):683-93.

37 European Commission. Public consultation on advanced therapy medicinal products. Cited June 23, 2020 Available from: http://ec.europa.eu/health/human-use/advanced-therapies/developments/2013_pc_atmp.htm

38 Baker AH, Ali RR, Thrasher AJ. Impact of BREXIT on UK Gene and Cell Therapy: The Need for Continued PanEuropean Collaboration. Hum Gene Ther. 2016 Sep;27(9):653-5.

39 Seymour LW, Thrasher AJ.Gene therapy matures in the clinic. Nat Biotechnol.2012;30(7):588-593. doi:https:// doi.org/10.1038/nbt.2290.

40 Robillard JM, Roskams-Edris D, Kuzeljevic B, Illes J. Prevailing public perceptions of the ethics of gene therapy. Hum Gene Ther. 2014 Aug;25(8):740-6.

41 IMI. Strategic Research Agenda for Innovative Medicines Initiative 2. Cited June 23, 2020. Available from: https://www.imi.europa.eu/sites/default/files/uploads/documents/About-IMI/research-agenda/IMI2_ SRA_March2014.pdf

42 IMI. Supporting the development of engineered T cells. Cited June 23, 2020. Available from: https://www.imi. europa.eu/sites/default/files/uploads/documents/apply-for-funding/future-topics/Topic_Tcells.pdf

43 IMI. Amended Annual Work Plan and Budget for 2019. Cited June 23, 2020. Available from: https://www.imi. europa.eu/sites/default/files/uploads/documents/reference-documents/AWPandBudget2019. Amendment1_FINAL.pdf

44 European Commission. Guidelines on Good Clinical Practice specific to Advanced Therapy Medicinal Products, C(2019) 7140 final. Cited June 23, 2020. Available from: https://ec.europa.eu/health/sites/health/files/files/ eudralex/vol-10/atmp_guidelines_en.pdf 
45 European Commission. Guidelines of 22.11.2017 Good Manufacturing Practice for Advanced Therapy Medicinal Products, C(2017) 7694 final. Cited June 23, 2020. Available from: https://ec.europa.eu/health/ sites/health/files/files/eudralex/vol-4/2017_11_22_guidelines_gmp_for_atmps.pdf

46 Germany first in EU to get Novartis' SMA gene therapy, costing almost 2m euros. Cited July 29, 2020. Available from: https://pharmaphorum.com/news/novartis-eyes-smart-deal-for-sma-gene-therapy-in-uk/\#: :text= Novartis $\% 20$ is $\% 20$ set $\% 20$ to $\% 20$ launch,the $\% 20$ end $\% 20$ of $\% 20$ the $\% 20$ year

47 Zolgensma's. "Day One” programme - an intriguing new venture for managed entry in Europe. Cited July 29, 2020. Available from:https://www.linkedin.com/pulse/zolgensmas-day-one-programmean-intriguingnew-venture-neil-grubert/

48 Jørgensen J, Hanna E, Kefalas P. Outcomes-based reimbursement for gene therapies in practice: the experience of recently launched CAR-T cell therapies in major European countries. J Mark Access Health Policy. 2020 Jan; 8(1):1715536.

49 Amid Zolgensma crisis, Novartis gets a gene therapy boost as NICE embraces Luxturna. Cited June 23, 2020. Available from: https://www.fiercepharma.com/marketing/amid-zolgensma-crisis-novartis-gene-therapyambition-gets-a-boost-as-nice-embraces

50 Tories promise new $£ 500 \mathrm{~m}$ fund to boost access to cutting-edge drugs. Cited June 23, 2020. Available from: https://www.ft.com/content/486726f4-0d6e-11ea-b2d6-9bf4d1957a67

51 Major German payers sign pay for performance agreements on CAR-Ts. Cited June 23, 2020. Available from: https://www.apmhealtheurope.com/freestory/0/64434/major-german-payers-sign-pay-for-performanceagreements-on-car-ts

52 Spark Prices Gene Therapy for Eye Disease at $\$ 850,000$, Introduces Outcomes-Based Rebates. Cited June 23, 2020. Available from: https://globalgenes.org/2018/01/03/spark-prices-gene-therapy-for-eye-disease-at850000-introduces-outcomes-based-rebates/

53 Gene therapy's next installment. Nat Biotechnol. 2019 Jul;37(7):697.

54 Kite to manufacture CAR T-cell therapy in Europe. Cited June 23, 2020. Available from: https://www.scienceboard.net/index.aspx?sec=sup\&sub=can\&pag=dis\&ItemID $=896$

55 IMI. Potential future IMI Call Topics. Cited June 23, 2020. Available from: https://www.imi.europa.eu/sites/ default/files/uploads/documents/apply-for-funding/future-topics/FutureIMICallTopics_Dec2018.pdf

56 Ylä-Herttuala S. The need for increased clarity and transparency in the regulatory pathway for gene medicines in the European Union. Mol Ther. 2012 Mar;20(3):471-2.

57 Fischer A, Dewatripont M, Goldman M. Benefit Corporation: a path to affordable gene therapies? Nat Med. 2019 Dec;25(12):1813-4.

58 EMA. CAT Work Plan 2020, EMA/CAT/520483/2019. Cited June 23, 2020. Available from: https://www.ema. europa.eu/en/documents/other/cat-work-plan-2020_en.pdf

59 Iglesias-López C, Agustí A, Obach M, Vallano A. Regulatory Framework for Advanced Therapy Medicinal Products in Europe and United States [Erratum in: Front Pharmacol. 2020 May 25;11:766. PMID: 31543814; PMCID: PMC6728416]. Front Pharmacol. 2019 Aug;10:921.

60 Gene Therapy: How “Advanced” is Europe? Cited June 23, 2020. Available from: https://www.regenhealthsolutions.info/2019/09/04/gene-therapy-how-advanced-is-europe/

61 Proposal for a regulation of the European Parliament and of the Council on the establishment of a Programme for the Union's action in the field of health - for the period 2021-2027 and repealing Regulation (EU) No 282/2014 ("EU4Health Programme"). Cited June 23, 2020. Available from: https://eur-lex.europa.eu/ resource.html?uri=cellar:9b76a771-a0c4-11ea-9d2d-01aa75ed71a1.0001.02/DOC_1\&format=PDF

62 European Commission. Pharmaceutical Strategy for Europe. Cited June 23, 2020. Available from: https:// ec.europa.eu/health/human-use/strategy_en

63 Germany: Investment Plan for Europe - EIB to provide BioNTech with up to €100 million in debt financing for COVID-19 vaccine development and manufacturing. Cited June 23, 2020. Available from: https://www.eib. org/en/press/all/2020-144-eib-to-provide-biontech-with-up-to-eur-100-million-in-debt-financing-forcovid-19-vaccine-development-and-manufacturing.htm

64 Communication from the Commission to the European Parliament. the Council, the European Economic and Social Committee and the Committee of the Regions, on enabling the digital transformation of health and care in the Digital Single Market; empowering citizens and building a healthier society, $\operatorname{COM}(2018) 233$ final. Cited June 23, 2020. Available from: https://eur-lex.europa.eu/legal-content/EN/TXT/HTML/?uri=CELEX: 52018DC0233\&from $=$ EN 